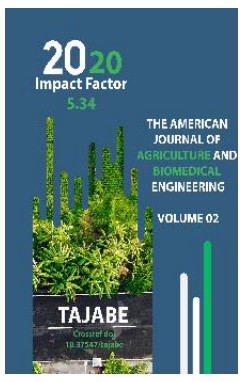

\title{
Creation And Implementation Of Silkworm Hybrids For Extreme Environmental Conditions
}

\author{
Gulbahor Erimmatovna Abdrimova \\ Head Of The Department Of Fishing And Sericulture, Doctor Of Philosophy Of Agricultural \\ Sciences (PhD) Nukus Branch Of The Tashkent State Agrarian University, Uzbekistan
}

Copyright: Original

content from this work may be used under the terms of the creative commons attributes 4.0 licence.

\section{ABSTRACT}

The article presents the possibilities of obtaining hybrids under unfavorable conditions of the Republic of Karakalpakstan using new hybrids and obtaining high yields of silkworm cocoons. The materials of the ecological point of view of the territories with the participation of sex-labeled rocks at the Grena stage are presented. And also the determination of the adaptability of the new Navruz-3, Navruz-4 hybrids and hybrids with the participation of parthenoclones of the agro-industrial complex $x$ Labeled1 hybrids to the extreme conditions of caterpillar growing.

\section{KEYWORDS}

Grena, silkworm mulberry, pupa, cocoon, new hybrid, parteonoclonus;

\section{INTRODUCTION}

Today, more than twenty countries around the world are engaged in the production of silkworms, receiving $840-860$ tons of cocoon raw materials. More than 60 countries are engaged in the production of silkworms and silk. "... the international turnover of silk sales is over $\$ 2-2.3$ billion. The leading countries in silk production are: People's Republic of China 
- 49.2\%, Italy - $17.0 \%$, India - 7.1\%, France - $6.1 \%$, Japan - $4.5 \%$, Korea - $4.4 \%$, Germany - $2.5 \%$, Great Britain - $2.1 \%$ and Uzbekistan - $0.005 \%$."1

\section{MAIN PART}

Intensive research on the scientific substantiation of new technologies for the care of silkworms in extreme conditions is carried out all over the world. Leading scientists from the southern regions of the People's Republic of China, India and Vietnam have carried out a number of experiments to create breeds and hybrids based on bivoltine silkworm breeds for extreme natural conditions, high yield achievements and the highest technological indicators that meet world standards have been obtained. In recent years, it was considered problematic to obtain breeds and hybrids with high yields adapted to abrupt weather changes under the influence of anthropogenic and environmental factors.

Scientists of our Republic have achieved a number of successes to date in creating silkworm breeds, with a large cocoon and adapted to ecologically harsh conditions. However, no attention has been paid to the creation of populations that ensure the development, growth and productivity of the silkworm; not enough attention is paid to scientific research work on obtaining highquality cocoons, increasing and improving the technological indicators of silk fiber in regions characterized by the presence of a biotic prerequisites. In Uzbekistan, a strategy of movements for 2017-2021 has been outlined, which approved the modernization of agriculture, in particular animal husbandry,

\footnotetext{
${ }^{1}$ www.inserco.org/
}

including the tasks of developing sericulture and a gradual increase in raw silk. ${ }^{2}$

Deep research on the cultivation and selection of new silkworm caterpillars, their adaptability to various natural conditions, the creation of new combinations of hybrids were carried out by such scientists of our Republic as V.A.Strunnikov, U.N. Nasirillaev, A.B. Yakubov, L.M.Gulamova, E.A. Larkina, E.Kh.Tajiev.

Scientists of foreign silkworm countries such as M.E.Braslavsky, B.Abbasov, A.Akimenko, B.Mametkuliev created and introduced silkworm breeds and hybrids adapted to the peculiar dry and relatively cool climate of Ukraine, Azerbaijan and Turkmenistan. Y.S.Reddi, B.Zhong, Y.Y.Chen, P.Trenov, D.Grekov created highly heterotic industrial hybrids by selection based on closely related correlative characters.

The purpose of the research is to select breeds and hybrids of silkworms adapted to the extreme conditions of the Republic of Karakalpakstan, among the newly created parthenogenetic clones, silkworm hybrids with high productivity, and sex-marked breeds.

The object of the research was silkworm breeds with peculiar properties, labeled and unlabeled by sex, parthenogenetic clones and hybrids of the silkworm Bombyx mori L.

The subject of the research is the main reproductive, biological and technological indicators of hybrids, silkworm breeds, demonstrating their genetic capabilities in the conditions of Karakalpakstan.

\footnotetext{
2 PF-4947- dated February 07, 2017 "On the strategy of actions for the further development of the Republic of Uzbekistan"
} 


\section{RESEARCH METHODS}

The following methods were used in the research: - traditional selection at all stages of development of the silkworm, taking into account the properties of sex-labeled breeds and parthenogenetic clones, according to the "Basic methodological rules for working with silkworm breeds"; selection based on the motor activity of the silkworm at the stage of revitalizing caterpillars and male butterflies, the method of activation of the unfertilized gerna to parthenogenetic development and the method of E.K.Merkuryeva for biometric data processing.

The scientific novelty of the research is as follows:

- $\quad$ For the first time from a scientific point of view, the genetic potential of hybrids was determined by partogenetic clones of the silkworm in natural conditions in unfavorable territories;

- Improved populations of breeds $\mathrm{C}-5, \mathrm{C}-10$, $\mathrm{C}-12$, resistant to extreme conditions of the Republic of Karakalpakstan, have been created;

- The possibility of obtaining hybrids in unfavorable from an ecological point of view territories with the participation of sex-labeled breeds at the stage of grena was proved;

- From a scientific point of view, the adaptability of hybrids of new Navruz-3, Navruz-4 and hybrids with the participation of parthenoclones of the agro-industrial complex $x$ Labeled-1 hybrids to extreme conditions of caterpillar cultivation was determined;
- It has been proved that in the conditions of the Republic of Karakalpakstan with the use of new hybrids, it is possible to obtain a high yield of silkworm cocoons.

\section{THE PRACTICAL RESULT OF THE RESEARCH}

Developed and introduced into life, with the participation of sex-labeled silkworm breeds and parthenogenetic clones, new combinations of hybrids adapted to the extreme conditions of the Republic of Karakalpakstan.

New hybrids Navruz-3, Navruz-4 have been obtained and put into practice with high indicators during cultivation, which have demonstrated their genetic potential in the environmentally difficult conditions of the Republic of Karakalpakstan.

In the difficult conditions of feeding the silkworm in the Republic of Karakalpakstan, hybrids Ipakchi 1 x Ipakchi 2, Ipakchi 2 x Ipakchi 1 and AIC $x$ Labeled 1 were raised, results with high biological and technological parameters were obtained.

External conditions play a decisive role in the realization of the genotype, in its most complete phenotypic manifestation. From genes and their primary protein products to a phenotypically mature organism, a number of processes go through, which can be influenced to varying degrees by environmental factors and other changes. This complex relationship between genotype and living conditions is known as genotype response rates.

Unlike other species of insects, the silkworm, as a strict monophage, feeds exclusively on mulberry leaves. The nutrient content of the leaves can vary depending on the mulberry 
variety and crop management practices.

So, [2; p.113-116] experimentally revealed varietal differences in the main elements (in grams) of feed eaten by 100 caterpillars:

\begin{tabular}{|l|l|l|l|l|}
\hline Mulberry variety & \multicolumn{1}{|c|}{$\begin{array}{c}\text { Total } \\
\text { nitrogen }\end{array}$} & $\begin{array}{c}\text { Protein } \\
\text { nitrogen }\end{array}$ & Sugar & Crude fat \\
\hline Variety SANIISH 14 & 13,30 & 11,87 & 26,28 & 12,24 \\
\hline Variety Tajik seedless & 15,72 & 14,07 & 35,55 & 15,36 \\
\hline In \% to the indicators of the variety & 118,2 & 118,5 & 135,3 & 125,5 \\
SANIISH 14, taken as 100\% & & & & \\
\hline
\end{tabular}

In special silkworm literature, the influence of environmental conditions on the growth, development and productivity of the poikilothermic silkworm is covered in sufficient detail.

Until the nineties, the cultivation of hybrid combinations of silkworms in production conditions on the same spring feeding, fully satisfied the need for silk. Currently, the task is to carry out repeated feeding. In hot, dry summers, not all breeds are able to fully manifest their genetic potential. Therefore, the need for the breeding and introduction of silkworm hybrids for extreme environmental conditions is increasing. Such hybrids can be used both in areas with a difficult natural environment, and on repeated feeding in the southern regions of Uzbekistan.

Based on the results of studies on the creation and implementation of silkworm hybrids adapted to ecologically harsh conditions, the following was obtained: in 2015 in the laboratory "Genetics and selection of the silkworm" 12 boxes of grena were prepared from each of the hybrids of the silkworm "Navruz-3", "Navruz-4", and sold in the farm "Mart ovul" of the Amu Darya region of the Republic of Karakalpakstan (reference Ministry of the Republic of Karakalpakstan No. 02 ( 09-2348 dated October 3, 2018); As a result, the yield from one box of grown silkworm caterpillars, compared to the control one, increased to $8.0 \mathrm{~kg}$., the economic profitability amounted to 45,000 soums, increased by $23.75 \%$;

8 boxes of grena were prepared, from the silkworm hybrids "Navruz-3", "Navruz-4" and sold in the farm "Shokhsanam-Khuzhaili" in the Khuzhayly district of the Republic of Karakalpakstan (certificate of the Ministry of the Republic of Karakalpakstan No. 02 / 092348 dated October 3, 2018 of the year). As a result, the yield of cocoon from one box increased by $7.5 \mathrm{~kg}$ and the economic profitability amounted to 61,500 soums; 
hybrids of silkworm caterpillars "Ipakchi $1 \mathrm{x}$ Ipakchi 2", "Ipakchi 2 x Ipakchi 1" and clonalbreed hybrid "APK x Labeled 1" were introduced in the farm "MukhabbatShermonova", Beruni region of the Republic of Uzbekistan (reference from the Ministry of the Republic of Karakalpakstan No. 02 / 09-2348 dated October 3, 2018). As a result, the yield per box increased by $7 \mathrm{~kg}$ more, the profitability was 66,500 soums.

\section{REFERENCES}

1. Resolution of the President of the Republic of Uzbekistan PP-2856 "On measures to organize the activities of the Association Uzbekipaksanoat" dated March 29, 2017. S. 1-15.

2. Uzbekistan Respubliki Presidency 2015 yil 29 dekabrdagi "2016-2010 yillarda qishlok khzhaligini yanada islok kilish va rivozhlantirish yaora-tadbirlari trisida" gi P2460-sonli opuarori, 5-7-6.

3. Finaeva N.M. Eating and digestibility of leaves of mulberry varieties with contrasting feeding effect. Proceedings of SANIISH, issue 9, Tashkent, 1976. -S.113120.

4. Yakubov A.B. Genetic basis for obtaining new valuable forms of silkworms using individual spontaneous mutagenesis. // Autoref. diss. doc. biol. sciences. Tashkent, 1997. -S.3-42.

5. Yakubov A.B., Kurbanov R.K., Pashkina T.A., Achildyev S.M. Method of selective selection of silkworm. // Copyright certificates, 1992.

6. Yakubov A.B., Kurbanov R.K., Strunnikov V.A. Radiomutation of the w2 locus in the $Z$ chromosome in the silkworm. // Silk. Tashkent, 1976. No. 2. - S. 9.

7. Yakubov Kh.Kh. Productivity and suitability for industrial technology of brown cows in hot climates. // Autoref. diss. Cand. s.kh. sciences. - Tashkent, 1993 .-- S. 16-17 